\title{
Passivization possibilities in double-accusative constructions
}

\author{
Vera Lee-Schoenfeld \& Gabriele Diewald*
}

\begin{abstract}
Based on a diachronic corpus search, this paper proposes that dative rather than accusative-marking on the first object of German double-accusative verbs like lehren 'teach' (as also discussed in Lang 2007) and the corresponding passivization possibilities stem from the first object being interpreted as Recipient (sympathyinvoking co-participant, see Lehmann et al. 2004) rather than animate Patient and the second object being interpreted as inanimate Patient rather than adverbial accusative. In addition, a formal case-based account of German active and passive (di)transitive constructions is offered, making a three-way distinction between (i) structural, (ii) predictable inherent, and (iii) idiosyncratic lexical case (in line with Woolford 2006).
\end{abstract}

Keywords. double-accusative verbs; passivization; dative case; kriegen/bekommen ('get') passive; diachronic corpus study; double-object construction; verbal argument structure; structural case; inherent case; lexical case

1. Introduction. In German, the double-accusative (DA) construction follows the exceptional ditransitive pattern of nominative subject plus two accusative objects (ACC $>$ ACC), rather than the regular pattern of a nominative subject plus one dative, and one accusative object (DAT $>$ ACC), and it exhibits irregular passivization behavior. This is shown in (1)-(3) (see also Czepluch 1988, Lang 2007, and Duden 2006, 2016), where canonical werden-passivization via nominative (NOM)-marking of neither the first object (2a) nor the second object (2b) leads to a completely well-formed utterance. Only if the first object is a DAT instead of ACC-object, can passivization target the second object by marking it with NOM case and result in a readily acceptable utterance (2c). The best solution, at least colloquially, seems to be to passivize the first object but to use kriegen or bekommen ('get') instead of the canonical passive auxiliary werden (3). This so-called kriegen-passivization normally turns a DAT-object into the NOM-marked subject.

(1) Jemand lehrt ihn den Seiltrick.

someone.NOM teaches him.ACC the.ACC rope-trick

'Someone is teaching him the rope trick.'
a. ? Er wird den Seiltrick gelehrt.
he.NOM is.PASS the.ACC rope-trick taught
b. ?? Der Seiltrick wird ihn gelehrt.
the.NOM rope-trick is.PASS him.ACC taught
c. Ihm wird der Seiltrick gelehrt.
him.DAT is.PASS the.NOM rope-trick taught
'He is being taught the rope-trick.'

(3) Er kriegt den Seiltrick gelehrt.

he.NOM gets.PASS the.ACC rope-trick taught

'He's getting taught the rope trick.'

\footnotetext{
* Authors: Vera Lee-Schoenfeld, University of Georgia (vleesch@uga.edu) \& Gabriele Diewald, Leibniz Universität Hannover (gabriele.diewald@germanistik.uni-hannover.edu).
} 
In English, on the other hand, the DA pattern represented by the German examples in (1) and (2a) - the English equivalent of which is shown here in (4) and (5a) - is the normal ditransitive pattern and comes with straightforward passivization possibilities (5b-c) (see also Woolford 1993). ${ }^{1}$

(4) Someone is teaching him the rope trick.

(5) a. He is being taught the rope trick.

b. * The rope trick is being taught him.

It is well-established that, in English, only the first ACC-object, whose case feature is valued with structural ACC case by agentive $v$ (in line with Burzio 1986), can become the subject under passivization. The second object can be argued to be lexically case-licensed by V (see Anagnostopoulou 2003 and Twiner 2016 for an overview of the relevant literature).

While it is obviously the single ACC-object that becomes the subject when the verb is monotransitive in German as well, the 2016 Duden Grammatik says, "Bei Verben mit doppeltem Akkusativ wird das personale Objekt zum Subjekt" (Duden 2016: 944) ('In the case of DA verbs, it is the animate object that becomes the subject'), but this source marks examples of both type (2a) and type (2b) with a "?". It is the 2006 Duden Grammatik (Duden 2006: 952) that indeed marks example type (2b), with the subject derived from the inanimate object, with a "**".

Interestingly, both the repair strategy shown in (2c), with the animate object being DAT instead of ACC-marked and the inanimate object becoming the subject under canonical werdenpassivization, and the repair strategy shown in (3), with the animate object becoming the subject but under kriegen-passivization, rely on the animate object of the DA verb being DAT instead of ACC-marked. In other words, these strategies rely on fitting the exceptional DA verb into the normal ditransitive pattern of DAT $>$ ACC, as shown in (6), with a typical ditransitive verb.

Jemand erklärt ihm den Seiltrick.
someone.NOM explains him.DAT the.ACC rope-trick
'Someone is explaining the rope trick to him.'

The remainder of the paper is structured as follows. Subsection 1.2 of this introduction takes a brief look at previous work on German DA verbs. Section 2 presents the results of new corpus work on the diachronic development of DA verbs from the ACC $>$ ACC pattern to the DAT $>$ ACC pattern, section 3 provides a sketch of a formal account of the facts, and section 4 concludes the paper.

1.2. PREVIOUS WORK ON DA VERBS: ACC $>$ ACC VS. DAT $>$ ACC. The only other DA verbs in German besides lehren ('teach') are kosten ('cost'), abfragen ('test/quiz'), abhören ('test/quiz'), and fragen ('ask'). In a 2007 seminar paper, Lang reports that there is a strong tendency to mark the first object with DAT rather than ACC and that the differentiation of object-types is based on

\footnotetext{
${ }^{1}$ Example (5b) is only acceptable for certain speakers if the indirect object pronoun him is phonologically reduced.

${ }^{2}$ Like the 2006 Duden Grammatik, Czepluch (1988) judges an example of type (2a) better than one of type (2b):

(i) ?dann ist der Junge das Lied gelehrt worden. (animate subj. and inanimate obj.) then has the.NOM boy the.ACC song taught was.PASS

(ii) *dann ist den Jungen das Lied gelehrt worden. (inanimate subj. and animate obj.) then has the.ACC boy the.NOM song taught was.PASS 'Then the boy was taught the song.'
} 
both semantics and syntax (Wegener 1985, 1986, Plank 1987, Braun 1993, Duden 1995, Wahrig 2003). If the first object is ACC-marked, then it is very much Theme/Patient-like, that is, maximally distinct from the subject in animacy. If the first object is DAT-marked, on the other hand, it is an animate Recipient. But if there is only one object, it must be ACC-marked, even if it is interpreted as animate Recipient. This is shown in (7), where lehren is used mono-transitively.

Der Pfarrer lehrt die Kinder / *den Kindern.
the pastor teaches the.ACC children / the.DAT children
'The pastor teaches the children.'

The passivization facts are reported to be unclear. When DAT replaces ACC, DAT tends to be used in S-initial position, and when there is no DAT-marking, NOM tends to be used in S-initial position. The recommendation is to simply avoid the passive with DA verbs.

The results of Lang's (2007) corpus search, for which he used newspaper corpora from the Institute of German Language (IDS) Mannheim and focused on the active use of lehren, yielded a total of 3678 tokens. Only about a quarter of all occurrences had two realized objects: $12 \%$ with the pattern of $\mathrm{ACC}>\mathrm{ACC} ; 6 \%$ with the pattern of $\mathrm{DAT}>\mathrm{ACC}$, and another $6 \%$ with the pattern of undifferentiated ACC/DAT (as in uns 'us') > ACC. About half of all occurrences had only one object, which was either a whole clause (propositional), an undifferentiated ACC/DAT-marked one, or an inanimate ACC-marked one. An example of the latter is given in (8).

Das Spiel lehrt einen leichtfertigen Umgang mit Geld.

the game teaches a.ACC careless handling with money

'The game teaches careless handling of money.'

Approximately another quarter had no object at all, as in (9).

Die Professorin lehrt an der Humboldt Universität.
the professor.FEM teaches at the Humboldt University
'The professor teaches at the Humboldt University.'

Lang concludes that, if lehren even occurs with two objects at all, it is relatively frequently used with a DAT-marked object (DAT > ACC), not only colloquially.

\section{A new corpus study on the development from ACC > ACC to DAT > ACC and what really happens in the passive. From the literature cited by Lang (2007) as well as his own investigation, we conclude that the first object of DA verbs corresponds to the necessarily animate indirect object of the prototypical ditransitive pattern. This means that the original animate Patient/Theme is interpreted as Recipient, a variant of the INDIRECTUS (a sympathy- invoking co-participant, see Lehmann et al. 2004), and that, depending on its semantic features, the second object of DA verbs can be interpreted as a typical inanimate Theme/Patient. Thus, we hypothesize that the second ACC-marked object was originally not a typical inanimate Patient but an adverbial ACC ("accusative of measure" in the case of kosten "cost') and can often be interpreted as a more Patient-like object so that the prototypical ditransitive schema (a scene of transfer) with a Recipient DAT becomes available.}

We searched the DWDS core corpus (http://www.dwds.de/ressourcen/kernkorpus/), which consists of different types of text (fiction and poetry, newspaper articles, science writing, functional writing) and contains about 100,000,000 words. Unlike Lang (2007), we targeted not 
only the active use of lehren but also (in fact, mainly) its passive use, and we chose two different time spans for our searches in order to be able to comment on possible diachronic developments.

Investigating the passive use, we searched for the past participle "gelehrt", excluding, for example, attributives and past participles following perfect auxiliaries. In the first time span (1900-1909), there were 39 passivized verbs among138 accessible tokens (146 total), and in the second time span (1990-1999), there were 29 passivized verbs among 44 accessible tokens (57 total).

As for the active use, we searched for "lehren", excluding, for example, attributives and nominalizations. In the first time span (1900-1909), there were 611 active verbs among 674 accessible tokens (706 total), and in the second time span (1990-1999), there were 180 active verbs among 223 accessible tokens (283 total). In order to facilitate direct comparison, we reduced the number of tokens from the first time span to 180., so that it matched the number of tokens from the second time span.

We focus on the passive use of lehren in subsection 2.1, move on to the active use in subsection 2.2, and finally draw overall conclusions regarding the development and variation of the use of the verb and its passivization behavior in subsection 2.3. We begin each subsection that reports on corpus search results (2.1 and 2.2) with tables summarizing our findings and follow up on them with discussion and representative examples.

\subsection{SEARCH 1: PASSIVE USE OF LEHREN.}

\begin{tabular}{lll}
\hline Time Span & $1900-1909$ & $1990-1999$ \\
\hline \hline$\sum$ Passive uses (accessible tokens) & $39(138)$ & $29(44)$ \\
\hline \hline DAT animate: wird den Kindern gelehrt & 5 & 1 \\
\hline DAT/ACC animate: wird uns gelehrt & 2 & 0 \\
\hline ACC animate: wird die Kinder gelehrt & 3 & 0 \\
\hline $\begin{array}{l}\text { ACC inanimate/propositional: wird den Seiltrick gelehrt / wird } \\
\text { gelehrt, dass... / wird gelehrt zu ... }\end{array}$ & 1 & \\
\hline Subject, referential or propositional (inanimate) & $36(34)$ & $28(27)$ \\
\hline Zero-Subject, expletive es & 3 & 1 \\
\hline Passive AUX werden & 39 & 28 \\
\hline Passive AUX kriegen & 0 & 1 \\
\hline
\end{tabular}

Table 1: Passives in first (1900-1909) and second (1990-1999) time span

What this table shows is that passive lehren is rarely used with both a passivized and an unpassivized object. If it does have an unpassivized object in addition to the passivized one (30\% in first time span and only 9\% in second time span), then we found that, most commonly, the subject is inanimate and the undifferentiated ACC/DAT-object (as in 10a) or the DAT-object (as in $10 \mathrm{~b})$ is animate. ${ }^{3}$

\footnotetext{
${ }^{3}$ In all our corpus examples, we only give glosses for the clause containing the relevant object(s) and/or subject, but we often include more of the sentence in order to provide speakers of German with as much context as possible.
} 
(10) a. Wir leiden unter der eigenen Winzigkeit, unter den engen Grenzen unseres Wissens und Lebens, seitdem uns die Endlosigkeit von Raum und Zeit gelehrt wird.

since us.ACC/DAT the endlessness of space and time taught is.PASS animate obj. inanimate subj.

(31.12.1903/ Belletristik/ Heyking, Elisabeth von: Briefe, die ihn nicht erreichten. In: Deutsche Literatur von Frauen, Berlin: Directmedia Publ. 2001 [1903], S.32339)

b. "Diesen drei jungen Männern ist nie christliche Nächstenliebe gelehrt worden",... these.DAT three young men has never Christian brotherly-love taught been.PASS animate obj. inanimate subj.

(31.12.1994/Belletristik/Jentzsch, Kerstin: Seit die Götter ratlos sind, München: Heyne 1999 [1994], S. 153)

There were only two examples with an animate subject and an inanimate object: one in the first time span where the inanimate object was a propositional infinitive complement (11a), and one in the second time span formed with kriegen (11b). The latter serves as clear evidence of ACCmarking of animate objects being replaced by DAT-marking because, as noted in section 1, the kriegen-passive targets DAT-objects.

a. Von Haus aus waren die germanischen Pferde klein und unansehnlich;

"sie werden auch nicht gelehrt," sagt Tacitus (Germ. 6),

they are.PAss also not taught says Tacitus

animate subj.

"verschiedenartige Wendungen nach unserer Art zu machen;... various turns according-to our.GEN way to make

inanimate obj. (clausal)

(31.12.1908/ Wissenschaft/ Fischer, Hermann: Grundzüge der Deutschen Altertumskunde, Leipzig: Quelle \& Meyer 1917 [1908], S. 101)

b. Nee, aber wie stehst du dazu, zu dem, $\quad$ was $\quad \underline{\text { wu }} \quad$ gelehrt kriegst ...

$$
\text { what you taught get.PASS }
$$

inanimate obj. animate subj.

(31.12.1991/ Belletristik/ Brussig, Thomas: Wasserfarben, Berlin: Aufbau-Taschenbuch-Verl. 2001 [1991], S. 179)

Our preliminary conclusions regarding the passivization facts concerning the DA verb lehren are as follows. When passivized, lehren is used more and more like a simple transitive verb, with the inanimate Theme/Patient ACC-object becoming the subject and no other object being realized (as in Hier wird Mathematik gelehrt 'Here, mathematics is taught'). As expected, passivization of the full DA argument structure of lehren, with one object becoming the subject and the other keeping its ACC-marking, is hardly found at all anymore. In order to shed light on the 'why' and 'how' of this development, we took a step back and revisited the active use of lehren. 
2.2. SEARCH 2: ACTIVE USE OF LEHREN

\begin{tabular}{lll}
\hline Time Span & $1900-1909$ & $1990-1999$ \\
\hline \hline$\sum$ of active uses investigated & 180 & 180 \\
\hline \hline Intransitive & 22 & 62 \\
\hline Transitive & 91 & 66 \\
\hline Ditransitive & 67 & 52 \\
\hline DAT animate & 1 & 3 \\
\hline DAT/ACC animate (instances of $u n s)$ & $28(26)$ & $19(18)$ \\
\hline ACC animate & 43 & 35 \\
\hline ACC inanimate & 153 & 106 \\
\hline Subject animate & 67 & 116 \\
\hline Subject inanimate & 113 & 64 \\
\hline
\end{tabular}

Table 2: Active uses in first (1900-1909) and second (1990-1999) time span

This table shows a strong increase of the intransitive use of lehren. We identified two different intransitive meanings: (i) 'show/illustrate/exemplify' with an inanimate subject (as in 12a), which occurred more frequently in the first time span, and (ii) 'be instructor (at a certain school/institution)' with an animate subject (as in 12b), which occurred more frequently in the second time span. We take this to be an indication of a lexical split. A new intransitive verb with meaning (ii) has been added to the existing (di)transitive verb lehren ('teach somebody something'). It seems that meaning (i) is on its way out.

(12) a. Aus diesen beiden Mineralen setzt sich auch, wie eingehende Untersuchungen gelehrt haben, die Grundmasse selbst zusammen.

as intricate investigations taught have

\section{inanimate subj.}

(31.12.1900/ Gebrauchsliteratur/ Jahrbuch des Vereins für wissenschaftliche Pädagogik, 1900, Bd. 32)

b. Er lehrt am Institut d'études européennes an der Universität Paris VIII. he teaches at-the Institut d'études européennes at the UniversityParis VIII animate subj. (12.09.1997/ Zeitung/ Die Zeit, 12.09.1997, Nr. 38)

As noted in section 1, the transitive use of lehren is only possible with an ACC (or undifferentiated ACC/DAT)-object. We identified two variants of meaning (ii), 'be instructor of a certain subject (inanimate object)' (as in 13a) and 'be instructor of a certain person (animate object)' (as in 13b). The transitive variant of meaning (i) 'show/illustrate/exemplify' (with a propositional object, as in 13c) still occurred frequently in the first time span, but much less so in the second one.

(13) a. Was aber hat man dann eigentlich gelehrt? what but has one.NOM then actually taught inanimate obj.

(31.12.1900/ Gebrauchsliteratur/ Jahrbuch des Vereins für wissenschaftliche Pädagogik, 1900, Bd. 32) 
b. Wer andere lehren beziehungsweise bilden will, muß zuvor studieren... who.NOM others teach or-that-is-to-say educate wants must beforehand study

animate obj.

(28.02.1997/ Zeitung/ Die Zeit, 28.02.1997, Nr. 10)

c. Ein Blick in die Vergangenheit lehrt,

a look into the past shows daß ... in der Verwaltung das Gelehrtentum vorherrschte.

that in the administration the learned-class predominated

clausal obj.

(31.12.1901/ Gebrauchsliteratur/ Baudissin, Wolf von u. Baudissin, Eva von: Spemanns goldenes Buch der Sitte. In: Zillig, Werner (Hg.), Gutes Benehmen, Berlin: Directmedia Publ. 2004 [1901], S. 3310)

As for the ditransitive use of lehren, in the first time span, we found consistent ACC-marking of the animate object, but the inanimate object was often propositional ('someone/something.NOM makes someone.ACC learn that something holds'). We call this the causative construction of lehren (see also Luraghi \& Zanchi To appear), which is indeed ditransitive but often shows up without actual DA-marking because a clause, of course, cannot be case-marked. An example is given in (14a). In the second time span, we found slightly more DAT-marked animate objects, but also more inanimate nonpropositional ACC-objects ('someone.NOM gives someone.ACC/DAT something.ACC to learn'). We call this the scene of transfer construction of lehren, which employs the DAT case to avoid DA-marking, as shown in (14b). Also noteworthy is the frequent use of undifferentiated ACC/DAT-marking on animate objects (e.g. uns 'us') in both time spans, which, again, results in no actual DA-marking, as exemplified in (14c-d).

a. Man hatte sie nie gelehrt, daß es noch etwas Höheresals sie gab. one had her.ACC never taught that there still somethinghigher than her existed animate ACC-obj. clausal obj. (31.12.1902/ Belletristik/ Janitschek, Maria: Die neue Eva. In: Deutsche Literatur von Frauen, Berlin: Directmedia Publ. 2001 [1902], S. 36059)

b. Um 1645 lehrte ein Chinese

around 1645 taught a Chinese-man den Töpfern ... die Bereitung besserer Schmelzfarben... the.DAT ceramists the.ACC preparation of-better enamel-colors

animate DAT-obj. (31.12.1993/ Wissenschaft/ o. A.: Lexikon der Kunst - P. In: Olbrich, Harald (Hg.), Lexikon der Kunst, Berlin: Directmedia Publ. 2001 [1993], S. 26460)
c. Das
hat uns
nicht erst
that.ACC
has us.ACC/DAT
animate ACC/DAT-obj.
not just
inanimate ACC-obj.

der Prozess gegen Stellbogen gelehrt...

the law-suit against Stellbogen taught

(05.04.1900/ Zeitung/ Die Fackel [Elektronische Ressource], 2002 [1900])
d. Was
lehrt
uns
das?
what.ACC
teaches us.ACC/DAT
that
inanimate ACC-obj. animate ACC/DAT-obj.

(30.09.1999/ Zeitung/ Die Zeit, 30.09.1999, Nr. 40) 
Our conclusions as to why and how the DA pattern (ACC $>$ ACC) is becoming the prototypical ditransitive pattern (DAT $>$ ACC) are as follows. With the older ditransitive use of lehren frequently involving a propositional inanimate object, ACC-marking of the animate object did not typically lead to ACC $>$ ACC and did not resemble a typical scene of transfer. Use of DAT instead of ACC for the animate object only became necessary or intuitive (in analogy with the prototypical ditransitive DAT > ACC verbs in German) when it became more common to use nonpropositional (PROP) inanimate objects. Furthermore, the re-interpretation of the formerly causative $(\mathrm{NOM}>$ ACC $>$ PROP) construction as a scene of transfer $(\mathrm{NOM}>\mathrm{DAT}>\mathrm{ACC})$ construction seems to be taking place via the critical context of the animate object having a caseundifferentiated ACC/DAT form, most frequently uns ('us').

2.3. OVERALL CONCLUSIONS REGARDING THE PASSIVIZATION OF LEHREN. To summarize, if an unpassivized object occurs at all, it is more commonly DAT than ACC-marked, and the subject is slightly more commonly derived from the underlying inanimate object (as in 'something was taught him' rather than 'he was taught something'). What speaks for the passivization pattern of 'he was taught something' over 'something was taught him' (and thus for the Duden judgment in (2a) and (2b), as well as Czepluch's (1988) judgments in (i-ii) in footnote 1), however, is that the inanimate object frequently used to be propositional and would therefore have resisted promotion to subject status. The best solution to passivizing ditransitive lehren seems to be the kriegen ('get')-passive, which targets DAT-objects and goes with the increasing use of DAT-marking on the animate object of DA verbs. We found one such passivization in the second time span (11b). A search of a spoken language corpus would likely yield many more instances of the kriegenpassive.

\section{A sketch of a formal account of active and passive case-marking possibilities in DA}

constructions. Based on the grammaticality distinction in (2a) vs. (2b) (Duden 2006, 2016, Czepluch 1988) and on the corpus search finding that the inanimate object used to be propositional (clausal), we propose the active base configuration in (15) (cf. Müller 1995, Grewendorf 2002, Woolford 2006, Haider 2010, and Bruening 2010). In the following paragraphs, we justify each case position (labeled by small Roman numerals) and provide relevant examples.

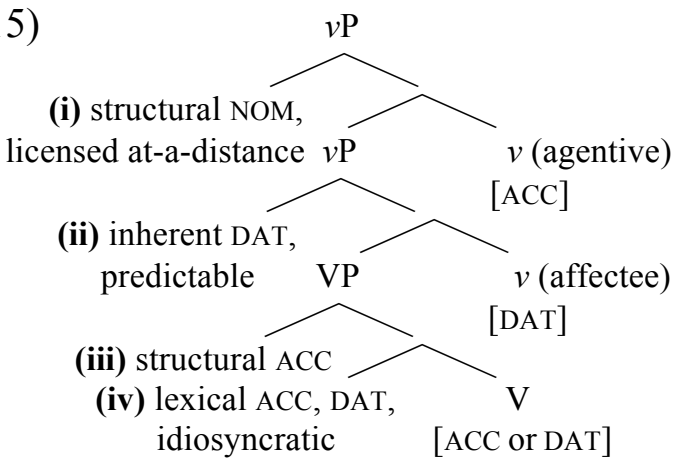

Position (iii), Spec VP, is the structural ACC case position, licensed by agentive $v$ (Burzio 1986), and it hosts the first object of a DA verb. An example is given in (16).
(16) Jemand lehrt ihn den Seiltrick.
someone teaches him.ACC the rope-trick
'Someone is teaching him the rope trick.' 
The first object becomes subject under passivization, as shown in (16').

(16') Er wird den Seiltrick gelehrt.

he.NOM is.PASS the rope-trick taught

'He is being taught the rope trick.'

Position (iii) is sister-to-V when position (iv) is not needed. It hosts the direct object of simple transitive and prototypical ditransitive verbs like lieben 'love' and geben 'give'.
a. Sie liebt ihn.
she loves him.ACC
'She loves him.'
b. Sie gibt ihm einen Kuss.
she gives him.DAT a.ACC kiss
'She gives him a kiss.'

The direct object, of course, becomes the subject under passivization. This is shown in (17').

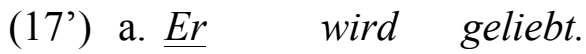

he.NOM is.PASS loved

'He is loved.'

b. Ein Kuss wird ihm gegeben.

a.NOMkiss is.PASS him.DAT given

'A kiss is being given to him'.

Position (iv), sister-to-V, is the lexical (idiosyncratic) ACC case or clausal complement position, licensed by $\mathrm{V}$, and it hosts the second object of a DA verb. An example is provided in (18).

(18) Jemand lehrt ihn den Seiltrick / Seil zu springen

someone teaches him the.ACC rope-trick/ rope to jump

'Someone is teaching him the rope trick / to jump rope.'

We predict that the second object does not passivize, which is obviously correct when it comes to clausal complements and also in line with the judgments in the Duden Grammatik (2006, 2016) and Czepluch (1988).

(18') *Der Seiltrick / * Seil zu springen wird ihn gelehrt. the.NOM rope-trick / rope to jump is.PASS him taught

'The rope trick / To jump rope is being taught to him.'

Position (iv) also hosts the inanimate DAT-object of exceptionally patterning verbs like aussetzen 'expose', an example of which is given in (19). The DAT case of this kind of object is lexical or idiosyncratic, licensed by $\mathrm{V}$ itself. As will become clear in a moment, we make a crucial distinction between lexical/idiosyncratic case on the one hand and inherent/predictable case on the other.
Man setzte ihn der Kälte aus.
one sat him.ACC the.DAT cold out 'People exposed him to the cold.' 
As expected, the structural ACC-object becomes subject under passivization, while the idiosyncratic DAT-object does not change. As shown in (19'), passivization with kriegen is impossible.

(19') Er wurde der Kälte ausgesetzt / *Die Kälte kriegte ihn ausgesetzt. he.NOM is.PASS the.DAT cold out-sat / the.NOM cold got him exposed 'He was exposed to the cold.'

Position (ii), Spec affectee $v \mathrm{P}$, is the inherent or predictable DAT case position, licensed by affectee $v$, and it hosts the first object of a DA verb when this is reinterpreted as the indirect object, the Recipient, of a prototypical ditransitive construction. This reinterpretation avoids DA marking (ACC > ACC). Example (20a) shows the DA verb lehren 'teach' following the DAT > ACC pattern, and (20b) shows the prototypical ditransitive verb erklären 'explain', which always follows this pattern.
a. Jemand lehrt ihm den Seiltrick. someone teaches him.DAT the rope-trick 'Someone teaches him the rope trick.'
b. Jemand erklärt ihm den Seiltrick. someone explains him.DAT the rope-trick 'Someone is explaining the rope trick to him.'

As shown in (20'), the inherent DAT-object becomes the subject under kriegen ('get')passivization.

(20') a. Er kriegt den Seiltrick gelehrt.

he.NOM gets the rope-trick taught

'He is getting taught the rope trick.'

b. Er kriegt den Seiltrick erklärt.

he.NOM gets the rope-trick explained

'He is getting the rope trick explained to him.'

Position (ii) also hosts the argument of monotransitive verbs selecting a DAT-object, like helfen 'help', gratulieren 'congratulate', and widersprechen 'contradict'. An example of helfen is given in (21). The DAT case here is again licensed by affectee little $v$, which, in this scenario, assigns not a Recipient but a Beneficiary role.

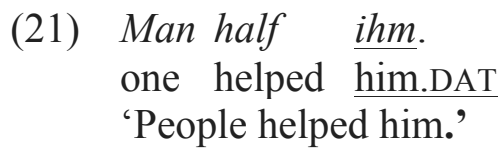

As shown in (21'), for some speakers, the inherent DAT-object of a verb like helfen can become the subject under kriegen-passivization (see also Beermann 2011).
$\begin{array}{lll}\text { Er } & \text { kriegte geholfen } . \\ \text { he.NOM got } & \text { helped }\end{array}$
'He was getting helped.'

We take this to indicate that the DAT case here is not idiosyncratic lexical but inherent case. It is predictably assigned to animate arguments and regularly alternates with NOM case for those speakers who allow (21'). In this sense, it is similar to structural ACC case. However, in line with 
Grewendorf 2002 and Haider 2010, we do not take the DAT-NOM alternation in examples like this to be evidence for DAT being structural case because, unlike the ACC-NOM alternation in canonical passivization constructions, DAT-NOM alternation depends on the case-changing nominal playing a certain type of semantic role. It is always some kind of Affectee, that is, a necessarily animate Goal, Recipient, or Bene/Male-ficiary (see also Bader \& Häussler 2013).

Position (ii) can also host a necessarily animate external possessor, a so-called "free dative" that is compatible with verbs selecting a (potentially possessed) internal argument and an optional Affectee argument, like ruinieren 'ruin' in (22). Here, DAT case is licensed by the Bene/Maleficiary role assigning version of affectee little $v$ (see Lee-Schoenfeld 2006, 2016).

Man ruinierte $\underline{i \mathrm{hm}} \underline{\mathrm{him} . \mathrm{DAT}}$ the garden
one ruined
'People ruined his garden.'

As predicted and shown in (22'), this inherent DAT case alternates with NOM case under kriegenpassivization.

(22') $\frac{E r}{\text { he }} \quad$ kriegte den Garten ruiniert.

he.NOM got the garden ruined

'He got his garden ruined.'

Finally, position (i), Spec agentive vP, is the external argument (proto-agent) position which hosts the subject of any (di)transitive or unergative verb. NoM-case is licensed at a distance by finite T (tense/agreement). An example with an unergative verb is given in (23).

$$
\begin{aligned}
& \text {..dass tatsächlich ein Junge im Chor mitsingt. } \\
& \text { that indeed } \frac{\text { a.NOM boy in-the chorus with-sings }}{\text { '...that there is indeed a boy singing in the chorus.' }}
\end{aligned}
$$

Position (i) is null when the verb is passivized or unaccusative. A passivization of the unergative verb mitsingen is shown in (23).

(23') ...dass $\varnothing$ im Chor mitgesungen wird.
that $\varnothing$ in-the chorus with-sung is PASS
'...that there is singing (along) in the choir.'

4. A summary and some connections to previous work. The analysis sketched in the tree structure in (15) correctly predicts the (un)grammaticality of most Double Accusative (DA) facts known from the literature (see (1)-(3) of section 1) and our corpus search (see section 2). It captures all but three instances of passivization from the first time span of our search, where exceptionally - the second (inanimate) object becomes the subject. The proposed account also captures well-known co-occurrence restrictions on DAT-objects (see e.g. Maling 2001 and Bosse 2015). Generally, there can only be one DAT-object at a time. The incompatibility of the two DAT-objects in (24), for example, falls out from the analysis because the affected animate arguments, Beneficiary and Recipient, compete for the same DAT-case-licensing position. The same holds for the combination of an optional possessor DAT and the obligatory DAT argument of verbs like helfen 'help' in (25). 
*Reich der Oma dem Opa bitte das Salz! pass the.DAT grandma the.DAT grandpa please the salt 'Pass grandpa the salt for grandma, please!" ${ }^{4}$

$$
\begin{aligned}
& \text { *Ich helfe dem Papa dem Kollegen. } \\
& \text { I help the.DAT dad the.DAT colleague } \\
& \text { 'I'm helping dad's colleague. }
\end{aligned}
$$

Overall, the proposed analysis is in line with much of the existing literature on ditransitive constructions, but there are also some important departures from previous proposals that we briefly address here. In line with Woolford 2006 and partly in line with Haider 2010 but contra Anagnostopoulou 2003, we make a crucial distinction between two types of non-structural cases, namely idiosyncratic lexical case on the one hand and (regular) predictable inherent case on the other. Also, as mentioned above, we agree with Grewendorf 2002 and Haider 2010 that the kriegen ('get')-passive is not evidence for DAT being structural case, but, contra Haider, we take it to be evidence for this kind of DAT being inherent rather than lexical case and for analyzing DAT-object-selecting verbs like helfen 'help' as inherent case licensors (via affectee $v$ ) rather than lexical case-licensors.

In line with Bruening 2010 and Bosse 2015, we argue, contra Pylkkänen 2008, that the base configuration of arguments is DAT > ACC, with each object being generated in its own verbal projection, namely in ApplP or affectee $\nu \mathrm{P}$ and VP, respectively. But contra Bruening and Bosse, our account requires no raising of arguments into a higher verbal projection in order to establish Pylkkänen (2008)'s "low applicative" transfer of possession relation. We argue that lexical VP and affectee $v \mathrm{P}$ can be considered one extended domain after $\mathrm{V}$-to- $v$ raising.

Furthermore, in line with Grewendorf 2002 and contra both Müller 1995 and Anagnostopoulou 2003, our DAT-case licensing position is above the ACC-case licensing position, so that we have the commonly assumed I(indirect) $\mathrm{O}$ (bject) $>\mathrm{D}$ (irect) $\mathrm{O}$ (bject) base configuration. This means that, unlike in Müller 1995, there is no need to posit A'-movement of the IO to the DAT-case licensing position. Our Spec affectee $v \mathrm{P}$ is a normal A-position. We tentatively propose that the complication of the IO not being able to bind a DO anaphor, as shown in (26), can be accounted for along the lines of Grewendorf 2002, where the DO anaphor is generated in AgrO above the IO-containing VP (see Grewendorf's (70), p. 63).

$$
\begin{aligned}
& \text { a. ...dass der Arzt } t_{i} \text { dem } \text { Patienten }_{j} \text { sich }_{i^{*}{ }_{j}} \text { im Spiegel zeigte. } \\
& \text { that the doctor the.DAT patient self in-the mirror showed } \\
& \text { '...that the doctor showed the patient himself in the mirror.' } \\
& \text { b. ...dass man die/*den Gäste }{ }^{*} n_{i} \text { einander }_{i} \text { vorgestellt hat. } \\
& \text { that one the.ACC/*DAT guests one-another introduced has } \\
& \text { '...that one introduced the guests to each other.' }
\end{aligned}
$$

A detailed extension of our analysis to these binding facts will be one of our goals for future research.

\footnotetext{
${ }^{4}$ Ethical datives, like mir 'me' in Reich mir.DAT der.DAT Oma doch bitte das Salz! ('Please pass grandma the salt, will you?') are the exception here. They are, however, best analyzed not as verbal arguments but as discourse markers (see Diewald 2016 for a recent overview of dative usages in German).
} 


\section{References}

Anagnostopoulou, Elena. 2003. The syntax of ditransitives: Evidence from clitics. Berlin: Mouton de Gruyter.

Bader, Markus, and Jana Häussler. 2013. How much bekommen is there in the German bekommen passive? In Artemis Alexiadou and Florian Schäfer (eds.), Non-canonical passives. 115-139. Amsterdam: John Benjamins.

Beermann, Dorothee. 2001. Verb semantics and ditransitivity. In Marc van Oostendorp and Elena Anagnostopoulou (eds.), Progress in Grammar: Articles at the 20th Anniversary of the Comparison of Grammatical Models Group in Tilburg. Dutch Royal Academy Publishing.

Bosse, Solveig Jana. 2015. Applicative Arguments: A Syntactic and Semantic Investigation of German and English. New York: Peter Lang Inc., International Academic Publishers.

Braun, Peter. 1993. Tendenzen in der deutschen Gegenwartssprache. Sprachvarietäten. $3^{\text {rd }}$ Edition. Urban-Taschenbücher, Volume 297. Stuttgart/Berlin/Köln: Kohlhammer.

Bruening, Benjamin. 2010. Ditransitive asymmetries and a theory of idiom formation. Linguistic Inquiry 41: 519-562.

Burzio, Luigi. 1986. Italian Syntax: A Government-Binding Approach. Dordrecht: Reidel.

Czepluch, Hartmut. 1988. Kasusmorphologie und Kasusrelationen. Linguistische Berichte 116: 275-310.

Diewald, Gabriele. 2016. Non-central usages of datives. In Gabriele Diewald (ed.), Special Issue: Non-central Usages of Datives. Language Typology and Universals 69. 1-14. Berlin/Boston: De Gruyter.

Duden. 1995. Drosdowski, Günther (ed.) Grammatik der deutschen Gegenwarts-sprache, Volume 4. $5^{\text {th }}$ edition. Mannheim: Dudenverlag.

Duden. 2006. Die Grammatik. Der Duden in zwölf Bänden, Volume 4. $7^{\text {th }}$ edition. Mannheim: Bibliographisches Institut.

Duden. 2016. Die Grammatik. Der Duden in zwölf Bänden, Volume 4. $9^{\text {th }}$ edition. Mannheim: Bibliographisches Institut.

Grewendorf, Günther. 2002. Minimalistische Syntax. Tübingen \& Basel: Francke/UTB.

Haider, Hubert. 2010. The Syntax of German. Cambridge University Press.

Lang, Peter. 2007. Grammatik und Norm: Direktes Objekt, indirektes Objekt und der doppelte Akkusativ. Ms. Universität Zürich.

Lee-Schoenfeld, Vera. 2006. German Possessor Datives: Raised and Affected. Journal of Comparative Germanic Linguistics 9: 101-142.

Lee-Schoenfeld, Vera. 2016. The syntax of external and internal possessor variation in German inalienable possession constructions. In Gabriele Diewald (ed.), Special Issue: Non-central Usages of Datives. Language Typology and Universals 69. 113-129. Berlin/Boston: De Gruyter.

Lehmann, Christian, Yong-Min Shin and Elisabeth Verhoeven. 2004. Direkte und indirekte Partizipation. Zur Typologie der sprachlichen Repräsentation konzeptueller Relationen (2 ${ }^{\text {nd }}$ edition). ASSIDUE, Arbeitspapiere des Seminars für Sprachwissenschaft der Universität Erfurt Nr. 13.

Luraghi, Silvia and Chiara Zanchi. To appear. Double accusative constructions and ditransitives in Ancient Greek. Folia Linguistica - Special issue on ditransitives.

Maling, Joan. 2001. Dative: The heterogeneity of the mapping among morphological case, grammatical functions, and thematic roles. Lingua 111(4): 419-464. 
Müller, Gereon. 1995. A-bar Syntax. A Study of Movement Types. Studies in Generative Grammar 42 .Berlin: Mouton de Gruyter

Plank, Franz. 1987. Direkte indirekte Objekte, oder: Was uns lehren lehrt. Leuvense Bijdragen 76: 37-61.

Pylkkänen, Liina. 2008. Introducing arguments. Cambridge, MA: MIT Press.

Twiner, Nicholas. 2016. Southern coreferential applicatives. Ms. University of Georgia. (Presented at BLS 42.)

Wahrig. 2003. Dittmann, Jürgen, Thieroff, Rolf, and Adophs, Ulrich (ed.) Fehlerfreies und gutes Deutsch. Gütersloh/München: Wissen Media Verlag.

Wegener, Haide. 1985. Der Dativ im heutigen Deutsch. Tübingen: Narr.

Wegener, Haide. 1985. Er bekommt widersprochen. Argumente für die Existenz eines Dativpassivs im Deutschen. Linguistische Berichte 96: 127-139.

Wegener, Haide. 1986. Gibt es im Deutschen ein indirektes Objekt? Deutsche Sprache 14: 1222.

Woolford, Ellen. 1993. Symmetric and asymmetric passives. Natural Language \& Linguistic Theory 11(4): 679-728.

Woolford, Ellen. 2006. Lexical case, inherent case, and argument structure. Linguistic Inquiry, 37(1): 111-130. 